\title{
In vitro regeneration and molecular characterization of some varieties of Lycopersicon esculentum Mill. in Bangladesh
}

\author{
M. Billah ${ }^{2}$, T. A. Banu ${ }^{1}$, M. Islam ${ }^{1}$, N. A. Banu ${ }^{2}$, S. Khan ${ }^{1}$, S. Akter ${ }^{1}$ and A. Habib ${ }^{1 *}$ \\ ${ }^{I}$ Plant Tissue Culture Section, Biological Research Division, Bangladesh Council of Scientific and Industrial Research \\ (BCSIR), Dhaka 1205, Bangladesh \\ ${ }^{2}$ Department of Biotechnology and Genetic Engineering, Islamic University, Kushtia-7003, Bangladesh
}

Received: 09 October 2017

Revised: 22 May 2018

Accepted: 03 December 2018

DOI: https://doi.org/10.3329/bjsir.v54i2.41667

\begin{abstract}
An efficient regeneration protocol was established for two varieties (BARI tomato-9 and BARI tomato-15) of tomato (Lycopersicon esculentum Mill.) using three explants namely cotyledonary node, cotyledonary leaf and hypocotyls. Among the three explants, maximum number of shoots was produced from cotyledonary leaf explants of BARI tomato- 15 on MS with $2.0 \mathrm{mg} / 1 \mathrm{BAP}$ and 0.5 $\mathrm{mg} / \mathrm{l}$ IAA. In this combination of BAP and IAA $86 \%$, on an average, cotyledonary leaf explants showed regeneration response 14.12 shoots/explants. Explants from hypocotyl showed best results in MS medium with $2.0 \mathrm{mg} / 1 \mathrm{BAP}$ and $0.2 \mathrm{mg} / 1 \mathrm{IAA}$ in both the varieties. In case of cotyledonary node, BARI tomato-15 showed 6.0 shoot/explant on MS with $2.0 \mathrm{mg} / 1 \mathrm{BAP}$ and $1.0 \mathrm{mg} / \mathrm{l} \mathrm{IAA}$. Molecular characterization of total ten varieties of tomato in Bangladesh was done by using six arbitrary oligonucleotide RAPD primers. A total of 140 bands were produced where the highest genetic distance $(0.6769)$ was found between BARI tomato-3 and Mintoo tomato and lowest distance $(0.1035)$ was observed between BARI tomato-7 and BARI tomato- 8 . This result will be useful for designing future breeding programs.
\end{abstract}

Keywords: Lycopersicon esculentum; Leaf explants; Multiple shoot; RAPD analysis

\section{Introduction}

Tomato (Lycopersicon esculentum Mill., Fam.: Solanaceae) is one of the most important edible and nutritious vegetable, native to Central and South America. It contains protein, lipid, carbohydrate, mineral and fiber. Tomato is a rich source of minerals, vitamins and organic acid, essential amino acids and dietary fibers. It is extensively cultivated throughout the world. In Bangladesh, it is cultivated in almost all kitchen gardens and also in the fields for its adaptability to wide range of soil and climate (Hossain et al., 2010). Due to its popularity, Bangladesh Agricultural Research Institute (BARI) has made several breeding programs to improve desirable characters such as fruit size, color, disease resistance, etc. in new tomato varieties. As a result, 13 varieties and 8 hybrid varieties of tomato were released by BARI (www.bari.gov.bd). In Bangladesh tomato cultivation and production is hampered due to various biotic and abiotic stresses. In overcoming such constraints of tomato production, breeding and biotechnological techniques have been applied elsewhere
(Oktem et al., 1999). Breeding program associated with biotechnological tools depends upon the development of an efficient in vitro plant regeneration system (Abu-El-Heba 2008). Molecular markers have become important tools in studying genetic diversity (Bered et al., 2005). Random amplified polymorphic DNA (RAPD) analysis through the polymerase chain reaction (PCR) has been widely used in molecular characterization and traces the phylogeny of diverse plant. Genetic information has been considered as an important factor and pre-requisite for plant improvement program (Chaudhuri et al., 1976). Since the morphological characterization does not provide accurate information necessary to distinguish different genotypes, further assessment of collected germplasms at the molecular level is required (Carmen de Vicente et al., 2006). The present study was conducted to test an efficient regeneration protocol and the genetic diversity of the local tomato varieties of Bangladesh using RAPD markers.

\footnotetext{
*Corresponding author e-mail: ahashan73@yahoo.com
} 


\section{Materials and methods}

In this study, two varieties of tomato namely, BARI tomato-9 and BARI tomato-15 were used for in vitro regeneration. While for molecular characterization, 10 other varieties namely, BARI tomato-2, BARI tomato-3, BARI tomato-7, BARI tomato -8, BARI tomato -9, BARI tomato-14, BARI tomato-15, Mintoo tomato, Delta tomato and Sawsan tomato were used. For the preparation of explants surface sterilized procedure were followed according to the protocol describe by Khan et al. (2017). The sterilized seeds were then transferred in autoclaved cotton soaked bottle for in vitro germination and growth of seeds. Different explants such as cotyledonary leaf, cotyledonary node and hypocotyls were excised from 8-10 days old seedling and inoculated on MS (Murashige and Skoog, 1962) media containing BAP, Kn and IAA, singly or in combinations for in vitro regeneration of shoots. Cultures were sub-cultured to fresh media regularly, at an interval of three to four weeks for maintenance. All cultures were maintained under fluorescent light of 20,000-25,000 lux intensity on a 16/8 (light/dark) hours at 25 $\pm 2^{\circ} \mathrm{C}$. For induction of roots, regenerated shoots $(2.5-4.0$ $\mathrm{cm}$ long) were excised and transferred to MS and half strength MS medium with 3\% sucrose without hormonal supplements. The plantlets with well-developed root system were transplanted in sterilized soil in small pots.

For RAPD analysis genomic DNA were isolated from fresh leaves of the 10 tomato varieties using CTAB method (Doyle and Doyle 1987). DNA is quantified by $0.8 \%(\mathrm{~W} / \mathrm{V})$ agarose gel electrophoresis and spectrophotometer (Analylikjena, Specord 50, Germany), respectively (Naz et al. 2013). Six RAPD primers such as OPA-1, OPA-4, OPA-5, OPA-10, Primer-6, and Primer-12 were used for RAPD analysis of 10 tomato varieties. Polymerase chain reactions (PCRs) were performed in $25 \mu \mathrm{l}$ of reaction mixture containing Taq buffer A 10x (10 mM Tris- $\mathrm{HCl}$ with1.5 mM $\left.\mathrm{MgCl}_{2}\right) 2.5 \mu 1$, primer $(10 \mu \mathrm{M}) 1.0 \mu \mathrm{l}$, dNTPs mix $(10 \mathrm{mM}) 0.5 \mu \mathrm{l}$, Taq DNA polymerase $(5 \mathrm{U} / \mu \mathrm{l}) 0.2 \mu \mathrm{l}$, Template $\operatorname{DNA}(25 \mathrm{ng}) 2 \mu \mathrm{l}$ and sterile de-ionized distilled water $18.8 \mu \mathrm{l}$.

DNA amplification is carried out in Thermal cycler and amplification products are separated by horizontal electrophoresis in agarose with ethidium bromide (10 $\mathrm{mg} / \mathrm{ml}$ ). DNA bands were observed on UV-transilluminator and photographed by a gel documentation system (ms major science UVDA). The photographs were critically discussed on the basis of presence (1) or absence (0), size of bands and overall polymorphism of bands. The scores obtained using all primers in the RAPD markers analysis were then pooled for constructing a single data matrix. This was used for estimating polymorphic loci, Nei’s (1972) gene diversity, genetic distance (D) and constructing a UPGMA (Unweighted Pair Group Method of Arithmetic Means) dendrogram among the germplasm using computer program "POPGENE 32" (Version 1.32).

\section{Results and discussion}

The present investigation was firstly aimed to establish an efficient regeneration protocol of two BARI tomato varieties namely BARI tomato-9 and BARI tomato-15. MS supplemented with various hormones were applied for induction of shoots from various explants such as cotyledonary leaf and node and hypocotyl. Multiple shoot formation with difference in numbers was observed in all hormonal treatments (Table I). Cotyledonary node showed direct organogenesis, where hypocotyls and cotyledonary leaf explants showed indirect shoot regeneration response.

In the present study, out of the three explants of tomato cotyledonary leaf showed maximum multiple shoot regeneration (average 14.12 shoots/explants) on MS with 2.0 $\mathrm{mg} / \mathrm{l} \mathrm{BAP}$ and $0.5 \mathrm{mg} / \mathrm{l}$ IAA in BARI tomato- 15 where $86 \%$ of explants responded ( Table I, Fig. 3 A and B). On the other hand, BARI tomato-9 showed best response on MS with 2.0 $\mathrm{mg} / \mathrm{l} \mathrm{BAP}$ and $1.0 \mathrm{mg} / \mathrm{l} \mathrm{IAA}$ from same explants with lower mean number (5.0) of shoots (Table 1). There are several reports of using BAP and IAA for shoot regeneration from cotyledonary leaf explants of tomato (Sarker et al. 2009, El-siddig et al. 2009).

When MS with $2.0 \mathrm{mg} / 1 \mathrm{BAP}$ and $0.2 \mathrm{mg} / \mathrm{l} \mathrm{IAA}$ were used $100 \%$ hypocotyl explants responded towards regeneration which was the best combination for hypocotyls in both the varieties of tomato (Fig 3C-D). In this combination of BAP and IAA average number of shoots was varied in two varieties of tomato where average 6.5 shoots/explants was obtained in BARI-9 and 9.2 shoots/explants in BARI-15 (Table 1). Kanakapura and Pradeep (2013) found best direct shoot regeneration on MS with $2.0 \mathrm{mg} / 1 \mathrm{BAP}$ and $0.1 \mathrm{mg} / 1$ IAA from hypocotyls explants of tomato. In case of cotyledonary node explants MS with $2.0 \mathrm{mg} / \mathrm{BAP}$ and 0.2 $\mathrm{mg} / \mathrm{l}$ IAA showed best response towards regeneration in BARI tomato-9 where 100\% explants responded towards shoot initiation (Fig $3 \mathrm{E}$ ) and mean number of shoots/explants was 4.2 (Table 1). On the other hand, BARI tomato-15 showed $100 \%$ regeneration response from cotyledonary node explants on MS with $2.0 \mathrm{mg} / \mathrm{l} \mathrm{BAP}$ and $1.0 \mathrm{mg} / \mathrm{l} \mathrm{IAA}$ with 6.0 average number of shoots/explants (Fig. 3F, Table 1). Kanakapura and Pradeep (2013) reported that MS with BAP $4.0 \mathrm{mg} / \mathrm{l}$ and IAA $1.0 \mathrm{mg} / 1$ combination was the best for cotyledonary node and cotyledonary leaf explants of tomato. 
Table I. Effect of different hormonal supplements on MS medium for in vitro shoot regeneration from various explants of BARI tomato-9 and BARI tomato-15.

\begin{tabular}{|c|c|c|c|c|c|c|c|c|c|}
\hline \multicolumn{4}{|c|}{$\begin{array}{l}\text { Hormonal } \\
\text { supplement (mg/l) }\end{array}$} & \multicolumn{6}{|l|}{ Explants } \\
\hline \multirow[t]{2}{*}{ BAP } & \multirow[t]{2}{*}{$\mathrm{Kn}$} & \multirow[t]{2}{*}{ IAA } & \multirow[t]{2}{*}{ Variety } & \multicolumn{2}{|c|}{ Cotyledonary node } & \multicolumn{2}{|c|}{ Cotyledonary leaf } & \multicolumn{2}{|c|}{ Hypocotyls } \\
\hline & & & & $\begin{array}{c}\% \text { of } \\
\text { responsive } \\
\text { explants }\end{array}$ & $\begin{array}{c}\text { Mean } \\
\text { number of } \\
\text { shoots } \\
\text { per explants }\end{array}$ & $\begin{array}{c}\% \text { of } \\
\text { responsive } \\
\text { explants }\end{array}$ & $\begin{array}{c}\text { Mean } \\
\text { number of } \\
\text { shoots } \\
\text { per explants }\end{array}$ & $\begin{array}{c}\% \text { of } \\
\text { responsive } \\
\text { explants }\end{array}$ & $\begin{array}{c}\text { Mean } \\
\text { number of } \\
\text { shoots } \\
\text { per explants }\end{array}$ \\
\hline 2.0 & 0.5 & - & BT-9 & 90 & 2.15 & 54 & 4.15 & 87 & 5.13 \\
\hline 2.0 & 0.5 & - & BT-15 & 60 & 3.33 & 70 & 5 & 66.6 & 4.5 \\
\hline 2.0 & 1.0 & - & BT-9 & 83 & 2 & 46 & 4 & 74 & 4.5 \\
\hline 2.0 & 1.0 & - & BT-15 & 100 & 2.00 & 63 & 5 & 80 & 4 \\
\hline 2.0 & 1.5 & - & BT-9 & 75 & 2 & 34 & 4 & 80 & 4 \\
\hline 2.0 & 1.5 & - & BT-15 & 83 & 2.22 & 60 & 4.5 & 53.3 & 4 \\
\hline 2.0 & 2.0 & - & BT-9 & 83 & 1.5 & 40 & 3 & 90 & 4.8 \\
\hline 2.0 & 2.0 & - & BT-15 & 100 & 2.16 & 40 & 4.0 & 70 & 3.6 \\
\hline 2.0 & 0.5 & 0.5 & BT-9 & 86 & 3 & 80 & 4.8 & 100 & 4.8 \\
\hline 2.0 & 0.5 & 0.5 & BT-15 & 100 & 3.20 & 86 & 3.8 & 73 & 4 \\
\hline 2.0 & 0.5 & 1.0 & BT-9 & 100 & 3.5 & 100 & 5.2 & 86 & 4.5 \\
\hline 2.0 & 0.5 & 1.0 & BT-15 & 100 & 4.00 & 86 & 4.0 & 100 & 5.2 \\
\hline 2.0 & - & 0.2 & BT-9 & 100 & 4.2 & 40 & 3.2 & 100 & 6.5 \\
\hline 2.0 & - & 0.2 & BT-15 & 100 & 4.00 & 80 & 7.4 & 100 & 9.2 \\
\hline 2.0 & - & 0.5 & BT-9 & 100 & 3.3 & 50 & 4.5 & 86 & 4.3 \\
\hline 2.0 & - & 0.5 & BT-15 & 100 & 5.50 & 86 & 14.12 & 100 & 6.42 \\
\hline 2.0 & - & 1.0 & BT-9 & 100 & 3 & 60 & 5 & 86 & 5 \\
\hline 2.0 & - & 1.0 & BT-15 & 100 & 6.00 & 80 & 12.25 & 100 & 7.2 \\
\hline
\end{tabular}

BT-9 = BARI tomato-9; BT-15 = BARI tomato-15

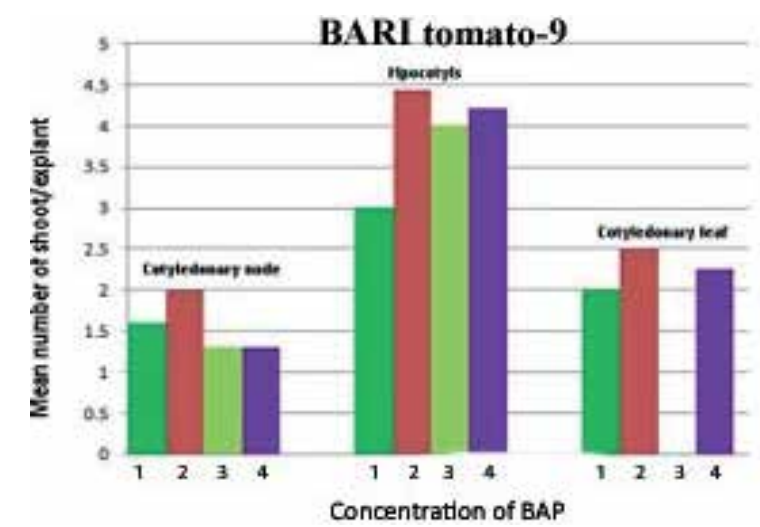

Fig. 1

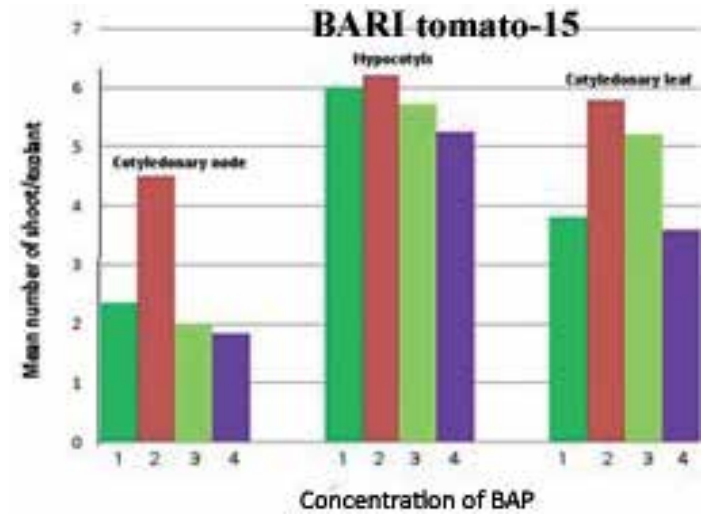

Fig. 2

Figs. (1-2). Effect of different concentration of BAP (1-4 mg/l) with MS medium for the regeneration of different explants of two BARI tomato varieties 
In the present study, different concentrations of BAP (1-4 $\mathrm{mg} / \mathrm{l})$ were used for regeneration of two BARI tomato varieties. MS medium with $2.0 \mathrm{mg} / \mathrm{l} \mathrm{BAP}$ was the most effective combination for adventitious shoots formation in all the explants and the varieties (Fig. 1-2).

Among the three explants hypocotyl showed best result in this combination of BAP (Fig. $3 \mathrm{G}$ and $\mathrm{H}$ ) where mean number of shoots per explants was 6.2 and 4.45 in BARI tomato-15 and BARI tomato 9 respectively which support the results of Mohamed et al. (2010).
Effects of BAP, Kn and IAA were examined on multiple shoot regeneration from three explants of tomato (Table-I). Among the three explants cotyledonary leaf of both the varieties showed best response towards shoot regeneration $(100 \%)$ on MS with $2.0 \mathrm{mg} / \mathrm{l} \mathrm{BAP}+0.5 \mathrm{mg} / \mathrm{K} \mathrm{Kn}+1.0 \mathrm{mg} / 1$ IAA with 5.2 average shoots/explant ( Fig 3I). Use of low dose of IAA $(0.5 \mathrm{mg} / \mathrm{l})$ with moderate dose of $\mathrm{Kn}(2.0 \mathrm{mg} / \mathrm{l})$ was found to be optimum for enhanced plantlet regeneration (Locky 1983). However Kartha et al. (1977) suggested that high levels of IAA were found to be promising probably due to genotypic and explants specificity. In the present study it

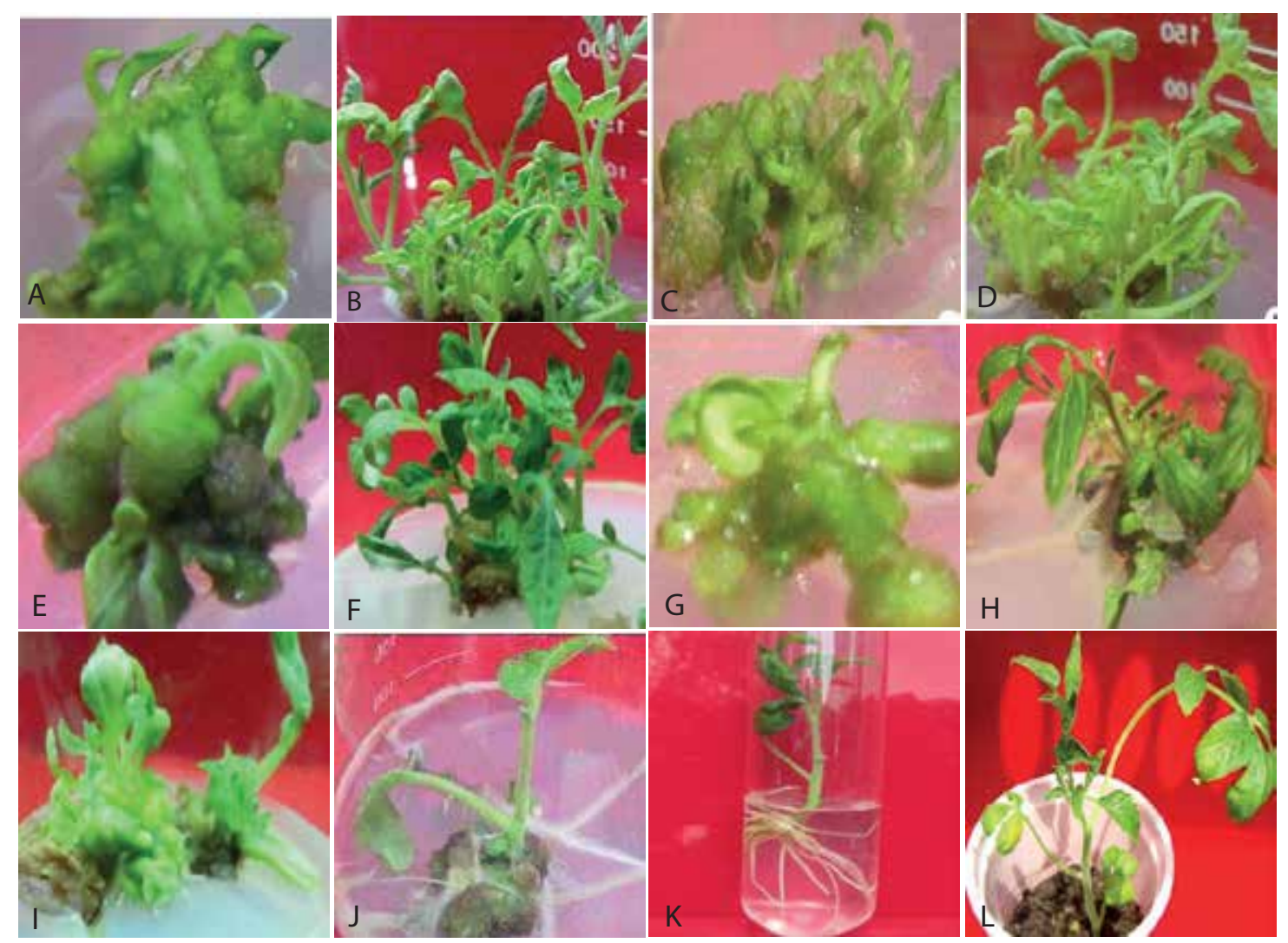

Fig. 3. (A-L). Regeneration of shoots using three explants of two tomato varieties. A. Multiple shoot initiation on MS with 2.0 $\mathrm{mg} / 1 \mathrm{BAP}+0.5 \mathrm{mg} / \mathrm{IAA}$ in case of BARI tomato- 15 from cotyledonary leaf explants; B. Development of multiple shoots on same media and same variety mention as Fig A; C Multiple shoot formation from hypocotyls explants on MS with 2.0 mg/l BAP and $0.2 \mathrm{mg} / 1$ IAA in BARI tomato-9; D. Elongation of multiple shoots from hypocotyls explants of BARI tomato-15 on same media mention as Fig C; E. Formation of multiple shoots from cotyledonary node explants on MS with $2.0 \mathrm{mg} / 1 \mathrm{BAP}$ and $0.2 \mathrm{mg} / \mathrm{l} \mathrm{IAA}$ in BARI tomato-9; F. Development of multiple shoots from cotyledonary node explants on MS with $2.0 \mathrm{mg} / 1$ BAP and $1.0 \mathrm{mg} / 1 \mathrm{IAA}$ in BARI tomato-15; G. Initiation of multiple shoots from hypocotyls explants on MS with $2.0 \mathrm{mg} / 1 \mathrm{BAP}$ in BARI tomato-15; H. Well developed shoots from hypocotyls explants on same media mention as Fig G; I. Shoot formation from hypocotyl explants on MS with $2.0 \mathrm{mg} / 1 \mathrm{BAP}+0.5 \mathrm{mg} / \mathrm{Kn}+1 \mathrm{mg} / \mathrm{l} \mathrm{IAA}$ in case of BARI tomato-15.; J. Formation of roots on same media and same variety mention as Fig I; K. Root formation on half strength of MS media without any hormonal supplements; L.Proper acclimatization of BARI tomato-9 in plastic pot. 
was also noticed that, roots were initiated from the shoots on MS medium supplemented with $2.0 \mathrm{mg} / \mathrm{l} \mathrm{BAP}+0.5 \mathrm{mg} / 1 \mathrm{Kn}$ $+1.0 \mathrm{mg} / \mathrm{IAA}$ (Fig. 3J), which support the observation made by Shyluk and Constabel (1976).
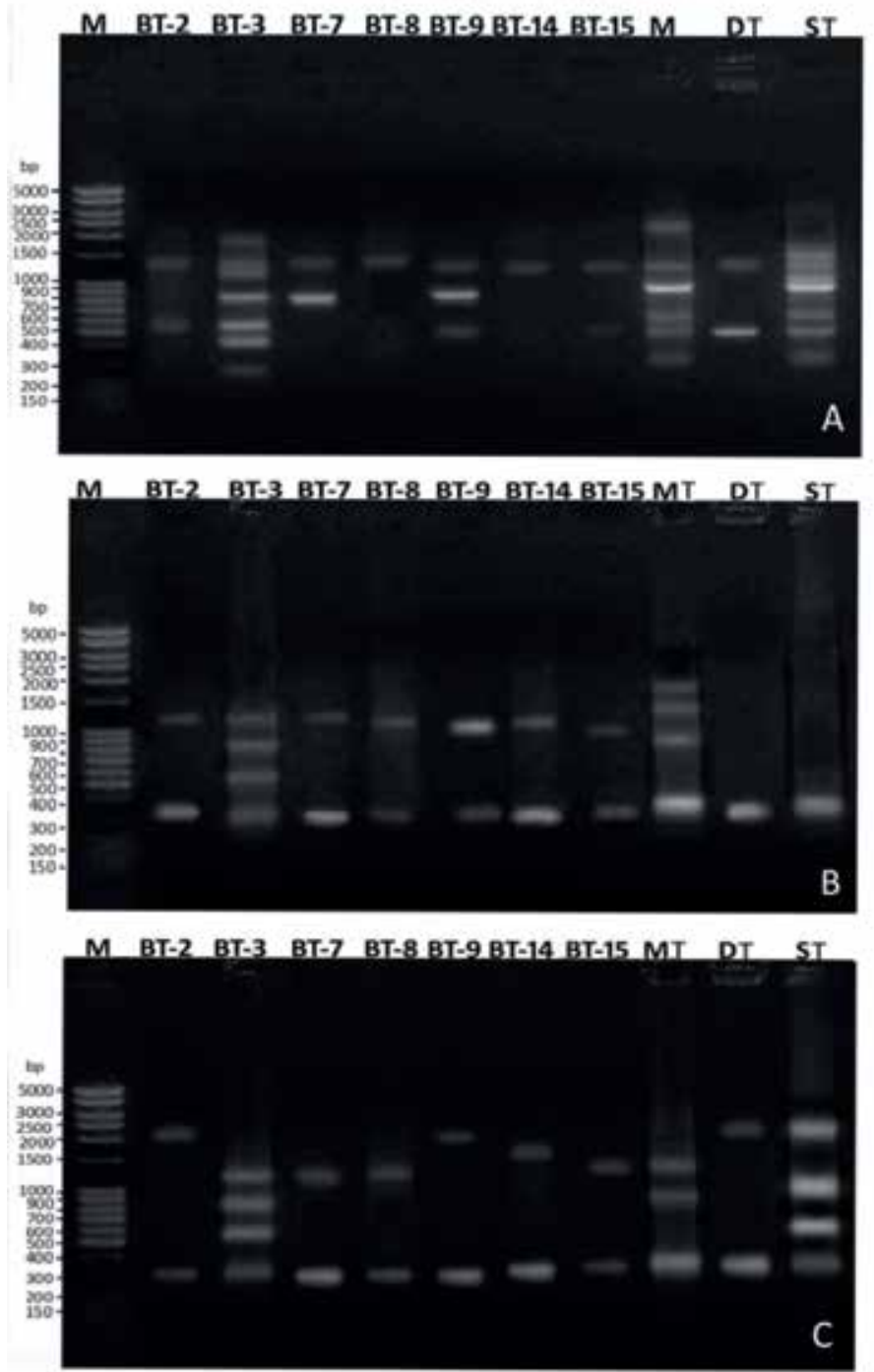

(Fig. 3 K). Though Devi et al. (2008) reported that the best rooting was found to be in half-strength medium supplemented with $0.2 \mathrm{mg} / \mathrm{I}$ IBA. Bhushan and Gupta (2010)
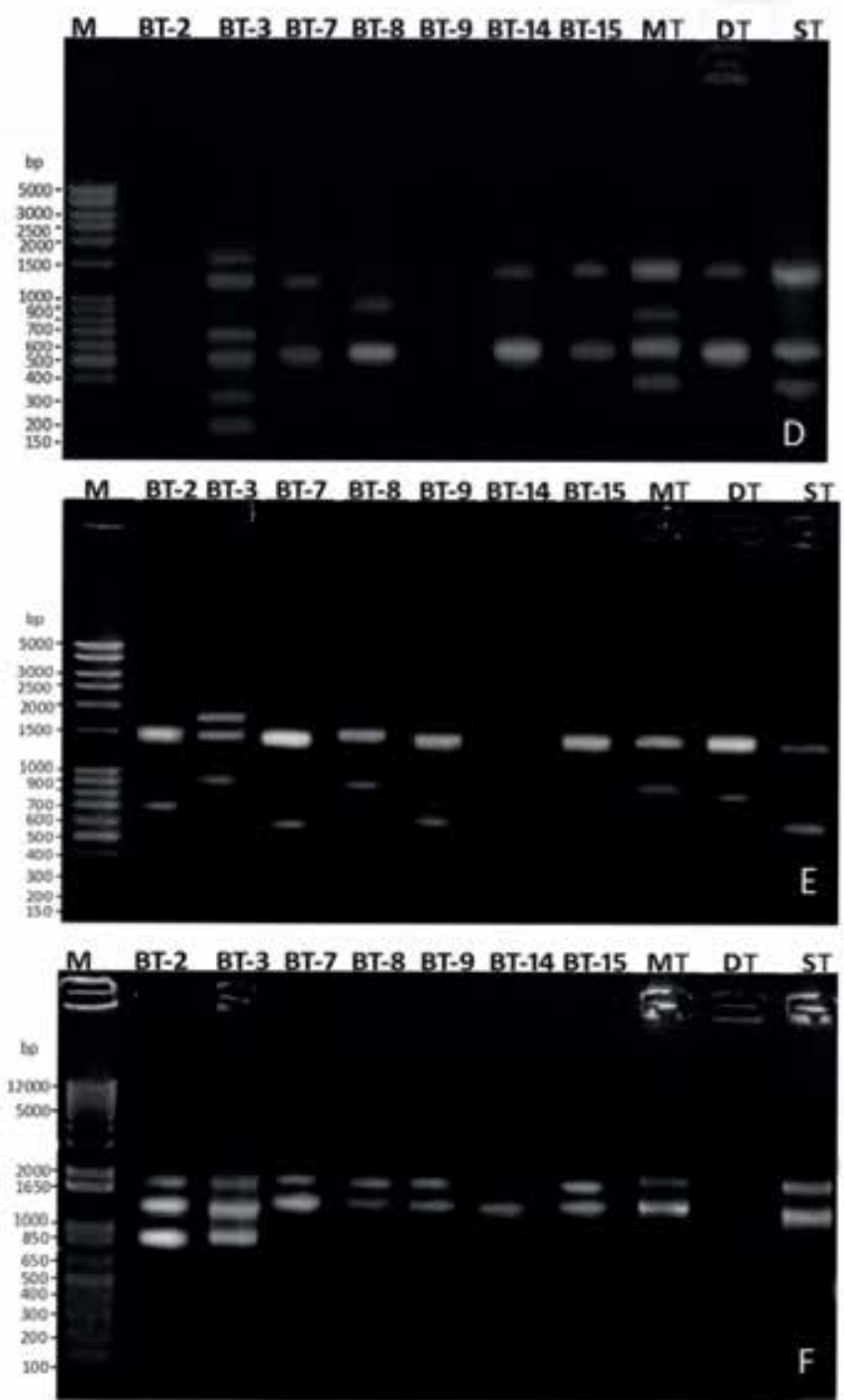

Fig. 4. RAPD analysis with different primers. (A) OPA-1 (5'-CAG GCC CTT C-3'); (B) OPA-4(5'-AAT CGG GCT G-3'); (C) OPA-5 (5'-AGG GGT CTT G-3'); (D) OPA-10 (5'-GTG ATC GCA G-3'); (E) primer-6 (5'-CCT GGG CTT A-3'); (F). primer-12 (5'-GTA TGG GGC T-3').

$\mathrm{M}=1 \mathrm{~Kb}$ DNA ladder, BT-2=BARI tomato-2, BT-3=BARI tomato-3, BT-7=BARI tomato-7, BT-8=BARI tomato-8, BT-9=BARI tomato-9, BT-14=BARI tomato-14, BT-15=BARI tomato-15, MT=Mintoo tomato, DT=Delta tomato and ST=Sawsan tomato.

Full and half strength of MS medium was tried for the formation of roots. Well developed and healthy roots were observed on half strength MS medium for both the varieties and Velcheva et al. (2005) also reported formation of roots in hormone free MS medium. Plantlets of BARI tomato-9 and BARI tomato-15 variety were transferred into small plastic pots for proper acclimatization (Fig. 3L). 


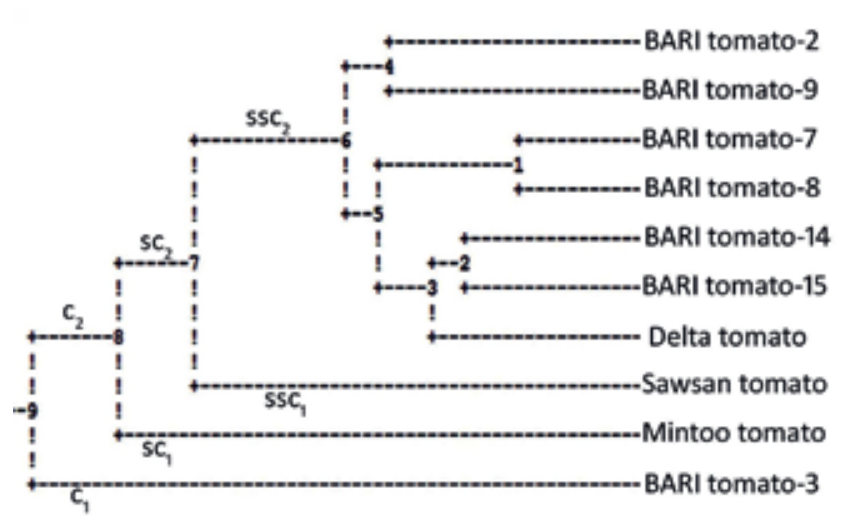

Fig. 5. UPGMA dendrogram constructed based on Nei's (1972) genetic distance summarizing the data on differentiation among 10varieties of tomato (Lycopersicon esculentum. Mill) by RAPD analysis.

In a separate set of experiment, six primer combinations, namely, OPA-1, OPA-4, OPA-5, OPA-10, Primer-6, and Primer-12 were used for RAPD analysis of 10 tomato varieties. Each primer combination showed different banding patterns. The 10 tomato varieties selected for the present study represent a broad spectrum of variation for several phenotypic traits and in their provenance. Only 3 common bands of different sizes were observed in three primer combinations (OPA-1, OPA-2 and OPA-5) (Fig. 4). The different sized common band indicated the sharing of similar DNA fragments among 10 varieties. Alam et al. (2012), was found two fragments of $1000 \mathrm{bp}$ and $700 \mathrm{bp}$ were common in the three tomato varieties (BARI tomato-2, BARI tomato-3 and BARI tomato-11) in Bangladesh in which the present study common fragment was $1200 \mathrm{bp}$ and $450 \mathrm{bp}$. Afroz et al. (2013) found common band with primer OPA-1 in three morphological forms of Alocasia fornicate (Kunth) Schott.
These results indicated that the sequences of CAG GCC CTT $\mathrm{C}$ (OPA-1) are available in different species. Although these 10 varieties had some common RAPD bands, sufficient polymorphisms regarding RAPD fragments were observed. The primer sequence, band size and banding pattern of 10 tomato varieties were shown in Table-II The six primers generated 140 distinct bands of which 110 were considered as polymorphic. An average of 23.3 countable bands and18.3 polymorphic RAPD bands generated per primer showing $80.70 \%$ polymorphisms which indicated the high level of polymorphisms. Band size ranging from $200-2400 \mathrm{bp}$ of PCR amplification products scored for all primers. Among the six primers OPA-2 and OPA-5 produced highest number of polymorphic bands. In contrast, the primer OPA-1 and OPA-5 generated the least number of polymorphic bands. A diverse level of polymorphism in different crops have been reported such as Chickpea 98.14\% (Rasool 2013), Brassica 98.03\% (Ghosh et al. 2009) and Chilli 90\% (Paran et al. 1998). Wide range of polymorphism in tomato varieties was reported earlier using RAPD markers. Alam et al. (2012), was reported $94.168 \%$ polymorphism on BARI tomato varieties of Bangladesh. Naz et al. (2013) scored a high degree of polymorphism in 25 tomato cultivars using RAPD markers. The molecular weight of bands analyzed by them ranged from 400 and 2500 bp of which $72.60 \%$ were polymorphic.

The values of pair-wise comparison Nei's (1972) genetic distance among 10 tomato varieties computed from combined data from the six RAPD primer ranged from 0.1035 - 0.6769 (Table-III). The highest genetic distance (0.6769) was found between BARI tomato-3 vs Mintoo tomato. The lowest (0.1035) genetic distance was observed between BARI tomato-7 and BARI tomato-8. The difference between the highest and the lowest value of genetic distance revealed the

Table II. Compilation of RAPD analysis in 10 varieties of tomato (Lycopersicon esculentum Mill.)

\begin{tabular}{|c|c|c|c|c|c|}
\hline Primer codes & $\begin{array}{l}\text { Sequences } \\
\left(5^{\prime}-3^{\prime}\right)\end{array}$ & $\begin{array}{l}\text { Total } \\
\text { bands }\end{array}$ & $\begin{array}{l}\text { Size ranges } \\
\text { (bp) }\end{array}$ & $\begin{array}{c}\text { Number of } \\
\text { Polymorphic bands }\end{array}$ & $\begin{array}{c}\text { Polymorphisms } \\
\text { (\%) }\end{array}$ \\
\hline OPA-1 & CAG GCC CTT C & 33 & $300-2400$ & 23 & 70 \\
\hline OPA-4 & AAT CGG GCT G & 22 & $450-1900$ & 12 & 54.54 \\
\hline OPA-5 & AGG GGT CTT G & 25 & $450-2400$ & 15 & 60 \\
\hline OPA-10 & GTG ATC GCA G & 23 & $200-1600$ & 23 & 100 \\
\hline Primer-6 & CCT GGG CTT A & 18 & $600-1750$ & 18 & 100 \\
\hline Primer-12 & GTA TGG GGC T & 19 & $600-1850$ & 19 & 100 \\
\hline Grand total & & 140 & & 110 & 80.7 \\
\hline
\end{tabular}


Table III. Summary of Nei's (1972) genetic distances of 10 varieties of (Lycopersicon esculentum Mill.)

\begin{tabular}{lllllllllll}
\hline Varieties & BT-2 & BT-3 & BT-7 & BT-8 & BT-9 & BT-14 & BT-15 & MT & DT & ST \\
\hline BT-2 & $* * * *$ & & & & & & & & & \\
BT-3 & 0.3042 & $* * * *$ & & & & & & & & \\
BT-7 & 0.1989 & 0.3267 & $* * * *$ & & & & & & & \\
BT-8 & 0.2397 & 0.3267 & 0.1035 & $* * * *$ & & & & & & \\
BT-9 & 0.1790 & 0.3973 & 0.1989 & 0.2397 & $* * * *$ & & & & & \\
BT-14 & 0.1989 & 0.3732 & 0.1790 & 0.1406 & 0.1989 & $* * * *$ & & & \\
BT-15 & 0.1989 & 0.3732 & 0.2191 & 0.2191 & 0.1596 & 0.1406 & $* * * *$ & & & \\
MT & 0.4473 & 0.6769 & 0.4220 & 0.4220 & 0.3973 & 0.3267 & 0.2822 & $* * * *$ & & \\
DT & 0.2397 & 0.4220 & 0.2191 & 0.2191 & 0.2397 & 0.1406 & 0.1790 & 0.2822 & $* * * *$ & \\
ST & 0.3973 & 0.6144 & 0.3267 & 0.3732 & 0.3497 & 0.2822 & 0.2822 & 0.3497 & 0.1989 & $* * * *$ \\
\hline
\end{tabular}

wide range of variability persisting among the 10 tomato varieties. High genetic distance values between varieties pair were found due to difference in genetic constituent. The varieties of lowest genetic distance can be used as parental source for breeding line to improve tomato varieties. Tabassum et al. (2013) reported the values of pair-wise genetic distance ranged from 0.1838 - 0.9049 in tomato variety of Bangladesh. Sharifova et al. (2013) had found the genetic similarity among evaluated genotypes ranged from $0.188-1.000$ on 19 Azerbaijan tomatoes. The lowest genetic distance was found between BARI tomato-7 vs BARI tomato-8. This result will be useful for designing future breeding programs.

\section{Conclusion}

From the results obtained in the present investigation it can be concluded that this regeneration protocol is simple, reproducible and genotype independent. This optimized regeneration protocol can be efficiently used for Agrobacterium mediated genetic transformation in tomato. To characterize the tomato variety of Bangladesh using PCR based RAPD primers, this information would be helpful for future breeding program as well as patenting each variety to prevent varietal piracy.

\section{References}

Abu-El-Heba GA, Hussein GM and Abdalla NA (2008), A rapid and efficient tomato regeneration and transformation system, Agriculture and Forestry Research 1,2(58): 103-110.
Afroz M, Sultana SS and Alam SS (2013), Karyotype and RAPD analysis of three morphological forms of Alocasia fornicata (Roxb.) Schott, Cytologia 78(3): 269-275. DOI:org/10.1508/cytologia.78.269

Alam SkS, Ishrat E, Zaman MY and Habib MA (2012), Comparative karyotype and RAPD analysis for characterizing three varieties of Lycopersicon esculentum Mill, Bangladesh Journal of Botany 41(2): 149-154. DOI: org/10.3329/bjb.v41i2.13439

Bered F, Terra TF, Spellmeier M and Neto JFB (2005), Genetic variation among and within sweet corn populations detected by RAPD and SSR markers. Crop Breed, Appl. Biotech. 5: 418-425.

Bhushan A and Gupta RK (2010), Adventitious shoot regeneration in different explants of six genotypes of tomato, Indian J. Hort. 67: 224-227.

Carmen de Vicente M, Felix Alberto G, Engels J, Ramanatha VR (2006), Genetic characterization and its use in decision-making for the conservation of crop germplasm In: The Role of Biotechnology in Exploring and Protecting Agricultural Genetic Resources, Eds. Ruane J, Sonnino A, Food and Agriculture Organization of the United Nations, Rome, Italy, pp 128-138.

Chaudhuri BK, Chaudhuri SK, Basak SL and Dana S (1976), Cytogenetics of a cross between two species of annual Crysanthemum, Cytologia 41: 111-121. 
Devi R, Dhailwal MS, Kaur A and Gosal SS (2008), Effects of growth regulators on in vitro micropropegenic response of tomato, Indian J. Biotechnol. 7: 526-530.

Doyle JJ and Doyle JL (1987), A rapid DNA isolation procedure from small quantities of fresh leaf tissues, Phytochem, Bull. 19: 11-15.

El-Siddig MAE, El-Hussein AA, Siddig MAM, Elballa MMA and Saker MM (2009), AgrobacteriumMediated Transformation and In Vitro Regeneration of Tomato (Lycopersicon esculentum Mill.) Plants Cv. Castlerock, Jour. of Genet. Eng. and Biotech. 7(1): 11-17.

Ghosh KK, Huque ME, Parvin MS, Akhter F and Rahim MM (2009), Genetic diversity analysis in Brassica varieties through RAPD marker, Bang. J. Agri. Res. 34(3): 493-503.

Hossain EM, Alam JM, Hakim AM, Amanullah ASM and Ahsanullah MSA (2010), An assessment of physiochemical properties of some tomato genotypes and varieties grown at Rangpur, Bangladesh Res. Pub. J. 4: 235-243.

Kanakapura KN and Pradeep SN (2013). Morphogenetic Potential of Tomato (Lycopersicon esculentum) cv. 'Arka Ahuti' to Plant Growth Regulators, Notulae Scientia Biologicae 5(2): 220-225.

Kartha KK, Champous S, Gamborg OL and Pahl L (1977), In vitro propagation oftomato by shoot apical meristem culture, J. Amer. Soc. Hort. Sci. 102: 346-349.

Khan S, Banu TA, Habib A, Islam M, Ferdousi A, Das N and Akter S (2017), In vitro regeneration of Piper nigrum, Bang. J. Bot. 46(2): 789-793.

Locky RD (1983), Callus formation and organogenesis by explants of six Lycopersicon species, Canad. J. Bot. 61: 1072-1078. DOI: org/10.1139/b83-115

Mohamed AN, Ismail MR and Rahman MH (2010), In vitro response from cotyledon and hypocotyls explants in tomato by inducing 6-benzylaminopurine, Afri. J. Biotec. 9(30): 4802-4807.

Murashige T and Skoog F (1962), A revised medium for rapid growth and bioassays with tobacco tissue cultures, Physiol. Plant. 15: 473-497.
Naz S, Zafrullah A, Shahzadhi K and Munir N (2013), Assessment of genetic diversity within germplasm accessions in tomato using morphological and molecular markers, J. Anim. Plant Sci. 23(4): 1099-1106.

Nei M (1972), Genetics distance between populations, American Nat. 106: 283-292.

Oktem HA, Bulbul Y, Oktem E and Yucel E (1999), Regeneration and Agrobactrerium- mediated transformation studies in tomato (Lycopersicone sculentum Mill.), Turk. J. Bot. 23: 345-348.

Paran I, Aftergoot E and Shifriss C (1998), Variation in Capsicum annuum revealed by RAPD and AFLP markers, Euphytica 99(3): 167-173.

Rasool S (2013), Genetic diversity as revealed by RAPD analysis among chickpea genotypes, Pak. J. Bot. 45(3): 829-834.

Sarker RH, Islam K and Hoque MI (2009), In vitro regeneration and Agrobacterium-mediated genetic transformation of tomato (Lycopersicon esculentum Mill.), Plant Tiss. Cult. Biotec. 19(1): 101-111. DOI:org/10.3329/ptcb.v19i1.5004

Sharifova S, Mehdiyeva S, Theodorikas K and Roubos K (2013), Assessment of genetic diversity in cultivated tomato (Solanum lycopersicum 1.) Genotypes using RAPD primer, J. Hort. Res. 21(1): 83-89.

Shyluk JP and Constabel F (1976), Morphogenetic investigations on in vitro leaf culture of tomato (L. esculentum Mill. cv. Starfire) and high frequency plant regeneration, Zeitschrift für Pflanzenphysiologie 77: 292-301. DOI:org/10.1016/S0044-328X(76)80002-5

Tabassum N, Sony KS, Hhajan SK and Islam MN (2013), Analysis of genetic diversity in eleven tomato (Lycopersicon esculentum Mill.) varieties using RAPD markers, Plant tiss. cult. Biotec. 23(1): 49-57.

Velcheva M, Faltin Z, Flaishman M, Eshat Y and Perl A (2005), A liquidculture system for Agrobacteriummediatedtransformation of tomato (Lycopersicones culentum L. Mill.), Plant Sci. 168: 121-130. DOI:org/10.1016/j.plantsci.2004.07.037 